\title{
Palliative care as an assumption of dignified death
}

\begin{abstract}
The evolution of medical science and its association with technological and commercial parameters become as a benchmark of medical exercise the cure paradigm. In this scenario of omnipotence, the medicine is putting your extreme paternalism on the end-of-life process, postponing as much as possible his suffering and violating their dignity. In contrast to the medicalization of death, it has been the practice of palliative care. A humanitarian medical practice that calls for preservation of patient dignity along the process of dying. It is focused on the patient's own will, palliative care offers a holistic care for a patient with terminal illness, it is free of therapeutic obstinacy. Thus, this work is aimed at demonstrating that the palliative care techniques are essential to promote dignified death in patients suffering from terminal illness. The methodology used consisted of a bibliographic research of interdisciplinary subjects relevant to the theme. Thus, based on the studies undertaken, it might realize that palliative care is an assurance measure that asserting the right of taking into care in a dignified death. It also aimed at implementing the patient self-determination to preserve his dignity in the final stage of his life.
\end{abstract}

Volume 2 Issue 6 - 2018

\author{
Cecília Lôbo Marreiro,' Andrezza Lôbo \\ Rodrigues $^{2}$ \\ 'Lawyer, Master in Constitutional Law by University of Fortaleza, \\ Brazil \\ ${ }^{2}$ Medical student in the Federal University of Cariri, Brazil
}

Correspondence: Cecília Lôbo Marreiro, Lawyer, Master in Constitutional Law by University of Fortaleza, Nurse by State University of Ceará, Specialist in Medical Oncology at Cearense School of Oncology, Coordinator of The Law Course of University Center of Ceará, Brazil, Email

cecilia.lobo@hotmail.com

Received: January 12, 2018 | Published: December 19, 2018

Keywords: terminal patient, dignified death, palliative care

\section{Introduction}

Inevitably, living means dying one day. From this reality, there is no way to depart of that, considering that the death, as the extreme limit of life, puts an end to the human life cycle.

This consciousness of finitude was assimilated in its entirety by medieval man, who, on his death bed, in the context of his home and in the company of those who loved him, experienced a participatory and autonomous dying process. There was, so to speak, a certain familiarity with death, which covered the dying man with dignity and resignation.

Otherwise, nowadays, death should be prohibited and concealed from the content of being. This dissociation was partly due to biotechnological advances which-not ignoring the handouts of medicinal products and therapeutic techniques for human survivalhave gone to intervene on death in different ways, to the point of ignoring it until the moment that it has already made an unquestionable reality.

It is through this frantic search for immortality that doctors rush about the patient's death, preventing it, extending it, disfiguring it. Within this vision, they become the "owners" of death, of its time, and of its circumstances.

Emerges from this scenario so devastating its greatest victim, the patient with terminal illness. The latter, suffering from an advanced disease and unbearable of curative treatment, will progress irreversibly to death in a short time. Thus, even in the face of its terminality, it is enclosed in the most secluded hospital bed, where, in most cases, extraordinary means are used, with the sole purpose of procrastinating its suffering and its death.

In response to the indignity of dying, in the face of his dying process, palliative care arises ${ }^{1}$. This humanized technique originated from the philosophy of hospices, whose main purpose was to assist

${ }^{1}$ Palliative care as active and total care for patients whose disease does not respond to the curative treatment anymore, prioritizing pain control, as well as the control of symptoms and psychological, social and spiritual problems, aiming at providing the best quality of life to patients and their families. (WHO, Definition of palliative care, 2002, on line) the terminally ill patient and his family with compassion and empathy. Delineating the historical profile of this term, Netto \& Spinola ${ }^{1}$ claim to be this remote at the time of the Crusades, where the wounded who fought for the causes of the Church were cared for in inns run by monks.

According to Pessini ${ }^{2}$ there are five guiding principles of palliative care: truthfulness, therapeutic proportionality, double effect, prevention and non-abandonment.

\section{Principle of truthfulness}

Communicate to the family and the patient the real situation in which he is, enabling his active participation in the decision-making process. For this purpose, it is necessary that this act be reviewed with great prudence and caution, because that is the only way the sick will grow in the understanding and acceptance of his truth.

\section{Principle of therapeutic proportionality}

This principle aims to defend the moral obligation to implement all therapeutic measures that have a direct relationship of proportion between the means employed and the predictable outcome. This relationship must be based on certain criteria, such as: the usefulness or uselessness of the measure; the alternatives of action, with their respective risks and benefits; the prognosis with and without the therapeutic measure established; and the costs, whether physical, psychological, moral or economic.

Thus, any intervention that disobeys this proportional relationship will favor the use of a futile and procrastinater treatment of suffering and death.

\section{Principle of double effect}

The symptomatology of the terminal patient is very complex. As a rule, it is externalized by intense physical pain and difficulty breathing, which favors, in most cases, the triggering of a state of anxiety, agitation and mental confusion.

To ease the suffering, several drugs are used - among them opioids - whose side effects are diverse. They may reduce blood pressure and/ or induce respiratory depression, as well as compromise the degree of 
the patient alertness and awareness. Based on this reality, the principle of double effect points out the conditions that must be observed for an act, that has two effects, a good and a bad, be lawful.

\section{Principle of prevention}

Predicting the possible complications and/or symptoms that are presented with greater frequency in the evolution of a particular disease, is a medical responsibility. Establishing the necessary measures to prevent such complications and to advise both the patient and his family members about the best courses of action to follow, on the one hand, to avoid unnecessary suffering and, on the other hand, to avoid disproportionate interventions.

\section{Principle of non-abandonment}

This principle aims not only to condemn the medical attitude of giving up the patient care that refuses a particular therapy, but also to abandon the one who has an illness in the terminal stage, erroneously being justified by the expression "nothing else can be done".

Thus, this work is aimed at demonstrating that the palliative care techniques are essential to promote dignified death in patients suffering from terminal illness. The methodology used was a bibliographic research of interdisciplinary subjects relevant to the theme.

Palliative care dissociates themselves from the use of extraordinary and exceptional methods; they send the patient, in the end, to a holistic care, capable of satisfying his physical and psychospiritual needs. In this way the process of dying acquires dignity and humanity. ${ }^{3-5}$

\section{Conclusion}

The dying process throughout the ages has metamorphosed. It detached from the "cocoon" in which death was considered familiar, accepted and dignified, to be attached to the form of a lonely death, denied and despicable to human quality.

To this interdicted death - which insists on departing from human existence - is added the practice of a futile and obstinatory therapy, whose essential purpose is to postpone, as far as possible, the dying process of the patient with terminal illness. In this context, it is confiscated the greater value of human being, dignity. This is the value that identifies the person as a human being and when an excessive and useless therapy is used only to establish the medical purposes, the terminal patient has his dignity violated. ${ }^{2}$

Thus, in response to this standard medical procedure about undignified death, in the late 1960s, there were movements in favor of a humanized therapy, for those whose termination is imminent. As a corollary of these claims, palliative care is taken, an assistive technique that turns to the sick person and not to the illness of the person.

The word, palliative, comes from the Latin vernacular pallium, which means cloak, mantle or cover. This etiology makes it easier to understand palliative care as the sick's protective mantle to prevent the deleterious effects of the disease progression. For Pessini ${ }^{2}$ this terminology is not restricted to physical care; it goes much further. It

${ }^{2}$ According to Kant (1986. P.77): In the kingdom of ends everything has either a price or a dignity. What has a price can be replaced by something else as its equivalent; what on the other hand is above all price and therefore admits of no equivalent has a dignity. includes a holistic character, which is also part of the biopsychosocial and spiritual dimensions of the human being.

In this way, medical care should prioritize the palliative care practice in patient with terminal illness, which will produce direct reflexes both in the preservation of his dignity and in his autonomy. In this way, this patient will no longer be a mere clinical case to be solved by the resources of the technoscience and will become considered a detailed person in its human nature.

Thus, medical care should prioritize the practice of palliative care in patients with terminal illness, which will produce direct reflexes both in the preservation of their dignity and in their autonomy. Therefore, this patient will cease to be a mere clinical case to be solved by techno-science resources and will come to be considered according to his human nature.

The effectiveness of the fundamental right to die in dignity does not mean to anticipate or postpone death, but to face it as a natural outcome of the life cycle, which in a way it is not different from life, it should be covered with full dignity.

Ignoring the existence of this right is to be indifferent to the persistent moans of the patient with terminal illness who is visibly tortured by a technicist medicine, he calls for a humanly assisted and completed death, in his time and manner.

In this way, replacing the cure paradigm with the care paradigm does not imply in omission or neglect about the treatment of the dying. To the contrary, it recovers the quality of life of this patient, once subtracted by the medicalization of death. Therefore, palliative care does not neglect medical technology, but aims to ensure that love and not just science are the driving force of care for the one who is facing death.

\section{Acknowledgments}

To Hospice and Palliative Medicine International Journal, for the opportunity to exposure my work, To my niece and coauthor of this work, Andrezza Lôbo Rodrigues, To the University Center Estácio FIC, where I perform my activities as a law professor.

\section{Conflicts of interest}

In this article there is no financial interest and no conflict of interest.

\section{References}

1. https://www.saraiva.com.br/geriatria-fundamentos-clinica-e-terapeutica2-ed2005-179302.html

2. https://www.estantevirtual.com.br/livros/cibele-andrucioli-de-mattospimenta-e-outros/dor-e-cuidados-paliativos-enfermagem-medicina-epsicologia/3479010561

3. Organização Mundial Da Saúse (OMS). Definição de cuidados paliativos. 2002.

4. http://www.dhnet.org.br/direitos/anthist/marcos/hdh_kant_metafisica costumes.pdf

5. https:/www.editoraappris.com.br/produto/1479-o-direito-morte-dignauma-anlise-tica-e-legal-da-ortotansia 